\title{
Effect of coinfection with influenza virus and bacteria on host damage
}

\author{
Ana María Castro, ${ }^{1 *}$ Carlos Cabello-Gutiérrez, ${ }^{2}$ Evelyn Pulido-Camarillo, ${ }^{3}$ Alexis E. García-García ${ }^{1}$ and \\ Armando Pérez-Torres ${ }^{3}$ \\ ${ }^{1}$ Universidad Nacional Autónoma de México, Faculty of Medicine, Department of Public Health; ${ }^{2}$ Laboratory of Virology, Instituto Nacional de \\ Enfermedades Respiratorias; ${ }^{3}$ Universidad Nacional Autónoma de México, Faculty of Medicine, Department of Cell and Tissue Biology. Mexico \\ City, Mexico
}

\begin{abstract}
Background: Influenza virus infection is often complicated by a bacterial infection, with this coinfection causing severe pneumonia. If not timely treated, the disease can cause death. Objective: To demonstrate, in animal models, that coinfection with influenza virus and bacteria that affect the respiratory tract causes multisystemic damage. Method: Six groups of mice were formed: a control group, one infected with the influenza virus, two infected with bacteria: Haemophilus influenzae and Streptococcus pneumoniae, respectively; and two co-infected with influenza virus and Haemophilus influenzae or Streptococcus pneumoniae, respectively. Results: Of the six groups of mice, only the group co-infected with influenza virus and Streptococcus pneumoniae showed damage to thoracic and abdominal organs. A decrease in serum cytokine levels was found in all study groups, which was more pronounced in the co-infected mice. Conclusions: The groups of mice infected with Streptococcus pneumoniae or influenza virus alone showed no damage, which indicates that coexistence of these infections caused the damage in the group of co-infected mice.
\end{abstract}

KEY WORDS: Influenza. Bacterial infection. Coinfection. Pro-inflammatory cytokines.

\section{Efecto de la coinfección por virus de la influenza y bacterias en el daño al hospedero}

\section{Resumen}

Antecedentes: La infección por el virus de la influenza con frecuencia se complica con una infección bacteriana, coinfección que provoca cuadros graves de neumonía, la cual puede ocasionar la muerte si no es tratada en forma oportuna. Objetivo: Demostrar en modelos animales que la coinfección por el virus de la influenza y bacterias que afectan el tracto respiratorio ocasiona daño multisistémico. Método: Se formaron seis grupos de ratones: un grupo control, uno infectado de virus de la influenza, dos infectados de bacterias: Haemophilus influenzae y Streptococcus pneumoniae, respectivamente; $y$ dos coinfectados de virus de la influenza y Haemophilus influenzae y Streptococcus pneumoniae, respectivamente. Resultados: De los seis grupos de ratones, solo en el grupo coinfectado de virus de la influenza y Streptococcus pneumoniae se observó daño en órganos torácicos y abdominales. En todos los grupos se encontró disminución de los niveles séricos de las citocinas, mayor en los ratones coinfectados. Conclusiones: Los grupos de ratones infectados solo de Streptococcus pneumoniae o el virus de la influenza no presentaron daños, lo cual indica que la coexistencia de estas infecciones fue la que ocasionó el daño en el grupo de ratones coinfectados.

PALABRAS CLAVE: Influenza. Infección bacteriana. Coinfección. Citocinas proinflamatorias.

\footnotetext{
Correspondence: 


\section{Introduction}

Viruses and bacteria have been documented to be the main etiologic agents in community-origin infections. ${ }^{1}$ Lower respiratory tract infections generally start with a viral infection (respiratory syncytial, influenza, parainfluenza viruses and adenovirus are the most common causative agents ${ }^{1}$ ); however, they are often complicated by bacterial infection, a combination that can trigger severe pneumonia presentations. Among the bacteria that most commonly cause pneumonia, Streptococcus pneumoniae (S. pneumoniae), Haemophilus influenzae (H. influenzae), Staphylococcus aureus (S. aureus), and Streptococcus pyogenes (S. pyogenes) have been identified.

In 2016, the World Health Organization reported that pneumonia was the leading cause of children mortality in the world. It has been estimated that, in 2015, it caused the death of approximately 920,136 children younger than five years; i.e., it caused $15 \%$ of all deaths of children younger than five years worldwide. ${ }^{2}$ In Mexico, respiratory tract infections continue to represent one of the top 10 causes of morbidity and mortality in this population group.

Acute respiratory infections initially affect the upper respiratory tract, but, depending on the pathogen and the host, they can spread to the lower respiratory tract and cause pneumonia. Influenza, whose etiologic agent is the influenza virus, is a highly contagious acute respiratory disease that affects all age groups and can be more serious in children and in the elderly. The infection is transmitted from person to person through aerosols generated by coughing or sneezing of sick people, which infect respiratory tract epithelial cells. Despite the use of vaccines, the impact of winter epidemics continues to be important in the world population.

In the 2018 influenza virus pandemic, the main cause of death was secondary bacterial infection; ${ }^{3}$ retrospective studies indicated that 50 to 100 million individuals died, out of whom $70 \%$ were positive for S. pneumoniae. ${ }^{4}$ A clear predisposition to coinfection with influenza virus and this bacterium has been demonstrated in subsequent pandemics, including the most recent one, in 2009, with H1N1 influenza virus; hospitalization rate ranged from $10 \%$ to $55 \%$ and mortality was due to $S$. pneumoniae. ${ }^{5}$

The influenza virus responsible for the 1918 pandemic was observed to cause severe lung damage, typified by bronchitis, bronchiolitis, alveolitis, predominance of neutrophils and acute alveolar edema, as well as presence of inflammatory cells and dead cells. ${ }^{6}$

Damage to the respiratory tract caused by coinfection has been documented. Changes in the respiratory tract caused by the influenza virus -including epithelial damage, respiratory function alterations and immune system receptors exposure- have been proposed to prepare the upper airway for secondary bacterial infection. ${ }^{7}$ Respiratory disease severity is increased by the conjunction of coinfection and alteration of the innate immune response. ${ }^{5}$

Once $S$. pneumoniae enters the respiratory tract, the innate immune response is activated, with alveolar macrophages participating by releasing pro-inflammatory cytokines and chemokines, which attract and recruit polymorphonuclear and mononuclear cells in the alveoli and lung parenchyma, ${ }^{8}$ which in turn initiates the inflammatory process inherent to the disease. If the infection is not treated in a timely manner, it evolves until causing patient death due to multi-systemic failure, which can be accompanied by coagulation disorders, mainly mucosal bleeding, as shown by blood in feces and urine.

During influenza pandemics prior to that of 2009, bacterial coinfections caused by $S$. pneumoniae, H. influenzae, S. aureus, and group A streptococci significantly contributed to morbidity and mortality. ${ }^{9,10}$

$H$. influenzae is a small gram-negative bacillus that can be part of the respiratory tract normal microbiome. When the bacterial cell membrane breaks, lipopolysaccharide is released, which is a molecule that participates in the inflammatory process and that in serum binds to lipopolysaccharide-binding proteins (LBP), a complex with high specificity to CD14. ${ }^{11}$ In patients with sepsis, LBP levels are high. ${ }^{12}$

S. pneumoniae is a gram-positive coccus, and several of its antigens have been characterized, among them substance $C$ (teicoic acid), which when binding to a betaglobulin called $\mathrm{C}$-reactive protein, present in patient serum, forms the substance C-C-reactive protein complex, which activates the complement cascade and, consequently, the release of inflammatory mediators. ${ }^{13}$

Pneumococci produce pneumolysin, which is released during lysis. High concentrations of pneumolysin oligomers are deposited on host cell membranes, where they form pores and cause cell lysis. Pneumolysin destroys the cilia of respiratory epithelial cells, breaks down the monolayer of respiratory tract epithelial cells, and decreases neutrophil bactericidal activity and migration; in addition, it activates the 
classical complement pathway. The acute inflammatory response is also triggered by different bacterial structures. The cell wall polysaccharide activates the complement alternate pathway and favors the production of anaphylatoxins $\mathrm{C} 3 \mathrm{a}$ and $\mathrm{C} 5 \mathrm{a}$, which increase vascular permeability..$^{13}$

For the research we present, six groups of mice were formed in order to demonstrate that the bacterial infection secondary to infection caused by the influenza virus is the cause of respiratory disease severity: a control group, one infected only with the pandemic H1N1 influenza virus, one only with $H$. influenzae and one with S. pmeumoniae; as well as two groups co-infected with the virus and each one of those bacteria, respectively. Damage to thoracic and abdominal organs was recorded, and the inflammatory process was assessed by determining serum pro-inflammatory cytokines.

Although secondary bacterial infections have been reported to cause the majority of deaths during influenza pandemics, little is known about the underlying mechanisms responsible for the synergy between influenza virus and bacteria.

\section{Method}

Male mice of the BALB/C strain, eight to 12 weeks old, were used, distributed in six groups, a control group and five groups in which influenza virus, $H$. influenzae or S. Pneumoniae, or the virus and one of the bacteria were intranasally inoculated. The microorganisms were diluted in phosphate-buffered saline (PBS):

- Group 1 or control: only received PBS.

- Group 2: inoculated with pandemic H1N1 influenza virus, $1 \times 10^{5} / 50 \mu \mathrm{L}$ of PBS.

- Group 3: inoculated with S. pneumoniae ATCC $49614,1 \times 10^{7} / 500 \mu \mathrm{L}$ of PBS.

- Group 4: inoculated with H. influenzae ATCC 49766, $1 \times 10^{7} / 500 \mu \mathrm{L}$ of PBS.

- Group 5: inoculated with influenza virus and S. pneumoniae, $1 \times 10^{7} / 500 \mu \mathrm{L}$ of PBS.

- Group 6: inoculated with influenza virus and $H$. influenzae, $1 \times 10^{7} / 500 \mu \mathrm{L}$ of PBS.

The number of colony forming units (CFU) of the bacteria was confirmed; $S$. pneumoniae was grown in blood agar and $H$. influenzae in chocolate agar. The real dose ranged from $1.2 \times 10^{7} \mathrm{CFU}$ to $1.4 \times 10^{7} \mathrm{CFU}$.

The groups were infected at the beginning of the project: Groups 5 and 6 were first infected with influenza virus and, at 72 hours, with $S$. pneumoniae and $H$. influenzae, respectively.
The study went on for four weeks; three mice from each group were sacrificed every four days.

Each mouse's weight of was recorded daily, and physical activity, hair and eye characteristics were assessed.

The mice were anesthetized with an injectable solution (Sedalpharma ${ }^{\circledR}$, Pet's Pharma, Mexico). Subsequently, blood was obtained from the heart, which was conventionally processed to obtain serum, which was stored at $-20^{\circ} \mathrm{C}$.

Serum pro-inflammatory cytokines were determined. Detection and quantification of proinflammatory cytokines interleukin (IL) $1 \beta$, IL-6 and tumor necrosis factor alpha (TNF $\alpha$,) were carried out by enzyme-linked immunosorbent assay (ELISA); PeproTech brand equipment was used and the manufacturer's instructions were followed.

\section{Results}

On the second post-coinfection day, the mice co-infected with influenza virus and $S$. pneumoniae had bristling hair. On the fourth day after coinfection, the sign of the hair was accentuated in co-infected groups 5 and 6 , in addition to presenting eye infections. On the sixth post-coinfection day, in addition to the above data, a mouse coinfected with influenza virus and $S$. pneumoniae showed respiratory distress. On seventh day post-coinfection, the signs continued and three mice with influenza virus and $S$. pneumoniae exhibited respiratory distress. The mice with the greatest coinfection effects were euthanized on the eighth day post-coinfection. On day 12 post-coinfection, some mice continued to have eye infection and bristling hair. The above signs progressively decreased in the remaining mice, which were finally sacrificed.

Mice infected with influenza H1N1 virus, S. pneumoniae, or $\mathrm{H}$. influenzae alone had no data consistent with infection in thoracic or abdominal cavity organs.

In the examination of the sacrificed mice, different alterations were identified depending on the time after coinfection with influenza virus and $S$. pneumoniae:

- At four days, pleural fluid was identified in one mouse; in one, collapse of the lung; in another, ileal hemorrhage.

- At eight days, one mouse had bloody pleural fluid, pulmonary hemorrhage and whitish nodules in the lung (Fig. 1); in another, thoracoabdominal hemorrhage and intestinal bleeding (melena) were observed; and in one more, intestinal vasodilation (Fig. 2); 
- At 12 days, one mouse exhibited pulmonary hemorrhage, and another, small hemorrhages in both lungs and intestinal vasodilation (Fig. 1).

Serum cytokines IL-1 $\beta$, IL- 6 and TNF $\alpha$ concentrations were determined four days after infection; decreased cytokines were found, both in mice with H1N1 virus, $H$. influenzae, and $S$. pneumoniae infection, and in control mice. The decrease was greater in the co-infected mice blood samples (Fig. 3).

Although the levels of all three cytokines did decrease in control mice, they remained constant throughout all four weeks, with only slight variations. $H$. influenza-infected mice showed the highest values of all three cytokines, and those infected with the H1N1 influenza virus, the lowest. The concentrations of all three cytokines were lower four days after coinfection; however, they were re-established in the H1N1 and $H$. influenza-co-infected mice, unlike the H1N1 and S. pneumoniae-co-infected animals (Fig. 3).

\section{Discussion}

During the 1918 pandemic, bacterial coinfection was implicated in almost all deaths of people infected with the influenza virus. The same happened in the 2009 pandemic: bacterial coinfection was observed in up to $34 \%$ of patients with pandemic influenza $A$ (H1N1) treated in intensive care units. Pathogens that colonize the nasopharynx (including $S$. aureus, S. pneumoniae and $S$. pyogenes) were most often isolated. ${ }^{14}$

Numerous articles have documented that type A influenza virus causes inflammation and necrosis in the respiratory tract epithelium. In different animal models, Wu et al. ${ }^{15}$ found that coinfection affected the adaptive immune response: compared to mice infected with influenza virus alone, mice coinfected with influenza virus and pneumococcus had significant body weight loss; IgG, IgM and IgA levels were decreased in the lung, as well as the number of plasma CD4 and B cells. Lethal coinfection reduced the size and weight of the spleen, as well as the number of $B$ cells. In mediastinal lymph nodes, lethal coinfection decreased germ center B cells, follicular T-helper cells, and plasma cells.

Walters et al. ${ }^{16}$ found that co-infected mice showed histopathological changes in more than half the alveolar parenchyma, with alveolar air spaces filled with inflammatory infiltrate, extensive acute suppurative pleuritis, generalized necrosis, bronchiolitis, and abundant fibrin thrombi in veins, venules, and capillaries.

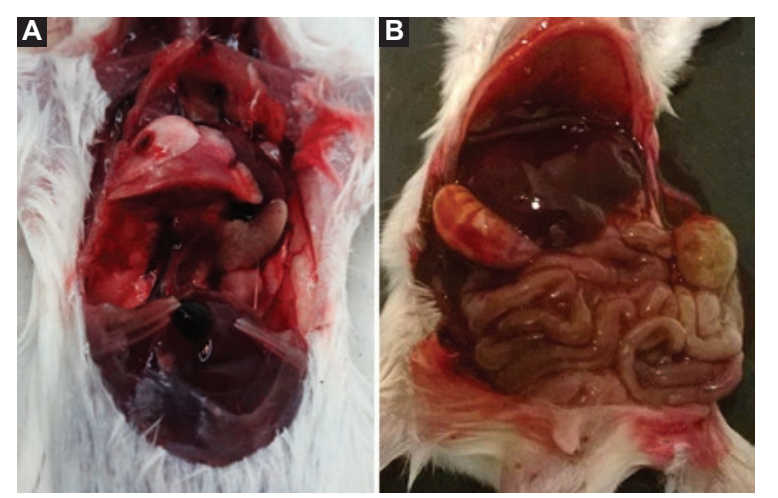

Figure 1. Findings in a mouse eight days after co-infection with influenza virus and S. pneumoniae. A) Whitish nodules in the lung. B) Thoracoabdominal hemorrhage and hepatosplenomegaly.

The above findings were similar to those observed in our research: mice co-infected with H1N1 influenza virus and $S$. pneumoniae showed bloody fluid in the pleura, hemorrhage and whitish nodules in the lung. Walters et al. documented an increased expression of genes that inhibit platelet function and coagulation only in co-infected mice, which are data that are consistent with those observed in our research.

In the mice that we studied, we detected thoracic and abdominal hemorrhages, as well as digested blood in the intestine (melena), which suggests that hemorrhages are due to an increase in clotting time, probably related to higher expression in the inhibition of genes involved in platelet function and coagulation, as demonstrated by Walters et al.

Patients with influenza virus infection who die are likely to have had bacterial coinfection; S. pneumoniae might have caused changes in clotting time, bleeding and fluid loss and, consequently, poor blood supply to the organs, multi-systemic failure, hypovolemic shock and death.

In a murine model coinfected with H1N1 influenza virus and $S$. pneumoniae, Wu et al..$^{15}$ demonstrated a decrease in the levels of specific $\lg G, \lg A$ and $\lg M$, as well as in the number of B cells, TCD4 cells and plasma cells in the lung and lymphoid organs. In our research, the concentration of pro-inflammatory cytokines showed a decrease in all mice groups; this decrease could be attributed to a decrease in the number of cells that produce these cytokines, as demonstrated by Wu et al.

\section{Conclusions}

In our study, the inflammation and necrosis caused by the influenza virus could probably have been 

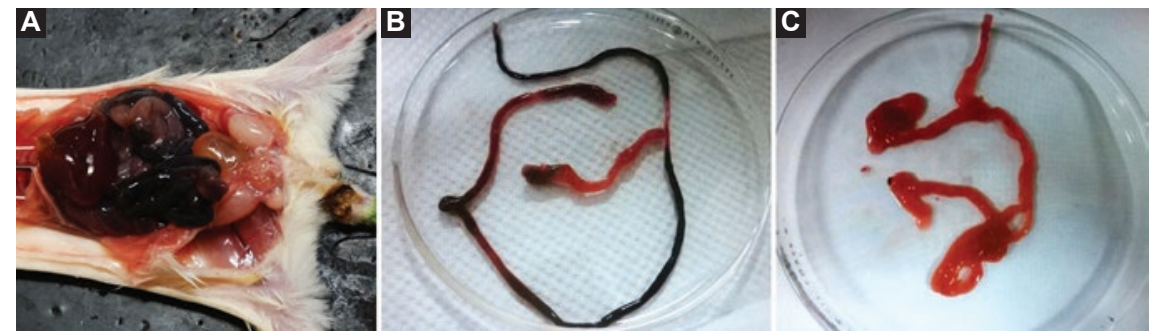

Figure 2. Findings in a mouse eight days after coinfection with influenza virus and S. pneumoniae. A) Thoracoabdominal hemorrhage. B) Intestinal hemorrhage (melena). C) Intestinal vasodilation.
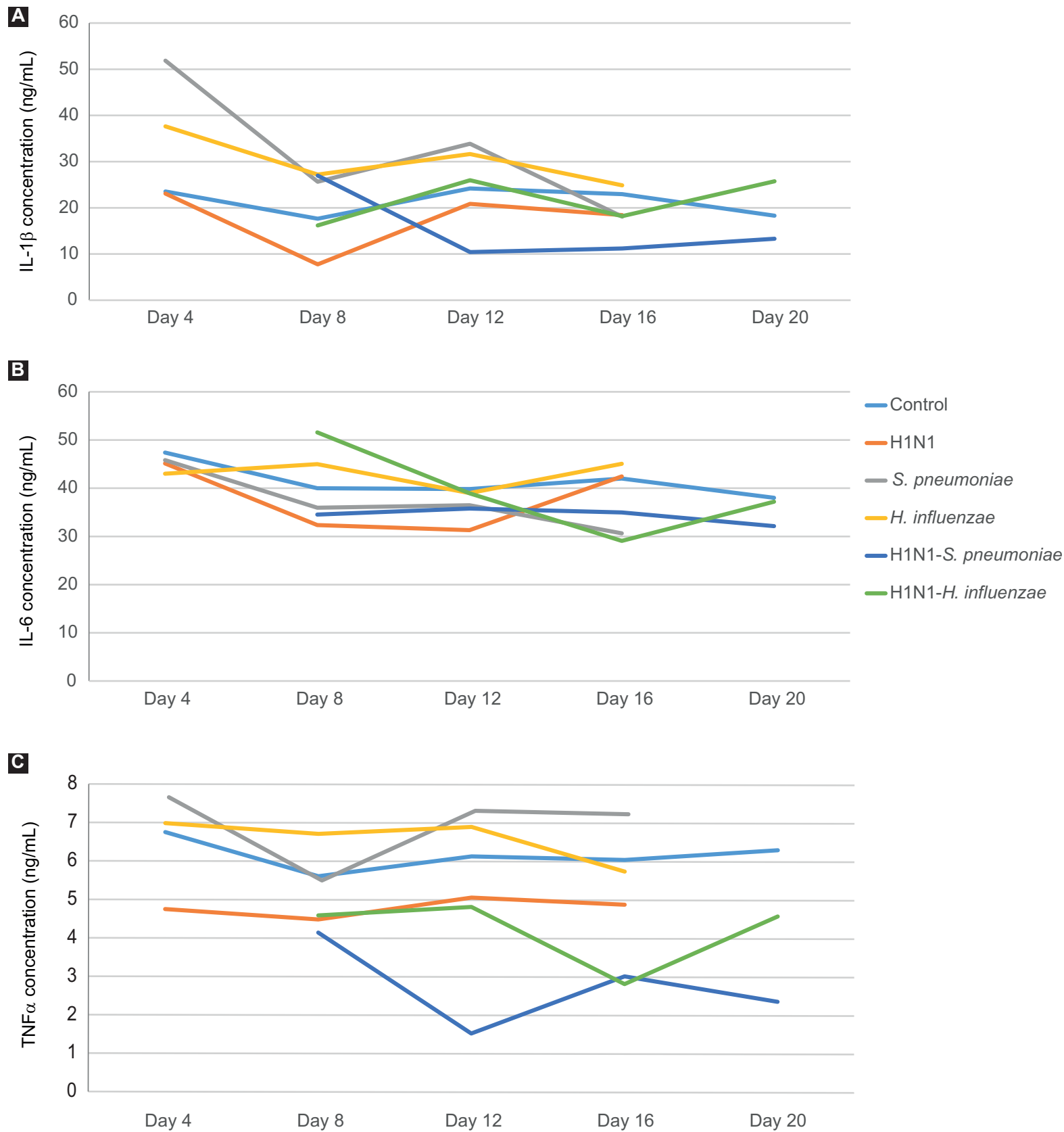

Figure 3. Cytokine concentration in serum of mice with H1N1 influenza virus or with S. pneumoniae and $\mathrm{H}$. influenzae bacteria, and of mice co-infected with H1N1 influenza virus and S. pneumoniae or H1N1 influenza virus and H. influenzae. A) Interleukin 13. B) Interleukin 6. C) Tumor necrosis factor $\alpha(T N F-\alpha)$. 
exacerbated by $S$. pneumoniae and evolved into bleeding and clotting time alterations, both in thoracic organs and abdominal cavity, particularly in the group of mice with thoracic and abdominal damage.

On the other hand, viral and bacterial virulence factors, as well as those of the host, also contribute to the pathogenesis of coinfection; therefore, the decrease in morbidity and mortality will depend on prevention with vaccines, as well as on early diagnosis and treatment.

\section{Acknowledgements}

This research was supported by the Faculty of Medicine of the National Autonomous University of Mexico.

\section{Conflicts of interest}

None

\section{Funding sources}

No specific grant was received from agencies in the public, commercial or non-profit sectors for this research.

\section{Ethical disclosure}

The authors declare that the performed procedures were carried out in accordance with the ethical standards on experimentation with animals and in adherence to the World Medical Association and the Declaration of Helsinki.

Confidentiality of data. The authors declare that no patient data appear in this article.
Right to privacy and informed consent. The authors declare that no patient data appear in this article.

\section{References}

1. Centro Nacional para la Salud de la Infancia y Adolescencia [Internet] Mexico: Prevención de la mortalidad infantil 2007-2012. Secretaría de Salud; 2008. Available at: http://www.censia.salud.gob.mx/descargas/ infancia/pronaremi.pdf

2. World Health Organization [Internet]. Geneva: Pneumonia. 2016 Aug 02. Available at: https://www.who.int/es/news-room/fact-sheets/detail/pneumonias

3. Morens DM, Taubenberger JK, Fauci AS. Predominant role of bacterial pneumonia as a cause of death in pandemic influenza: implications for pandemic influenza preparedness. J Infect Dis. 2008;198:962-970.

4. Chien YW, Klugman KP, Morens DM. Bacterial pathogens and death during the 1918 influenza pandemic. N Engl J Med. 2009;361:2582-2583.

5. McCullers JA. The co-pathogenesis of influenza viruses with bacteria in the lung. Nat Rev Microbiol. 2014;12:252-262.

6. Xiao YL, Kash JC, Beres SB, Sheng ZM, Musser JM, Taubenberger JK. High-throughput RNA sequencing of a formalin-fixed, paraffin-embedded autopsy lung tissue sample from the 1918 influenza pandemic. J Pathol. 2013;229:535ロ545. DOI:10.1002/path.4145.

7. McCullers JA. Insights into the interaction between influenza virus and pneumococcus. Clin Microbiol Rev. 2006;19:571-582.

8. Haste L, Hulland K, Bolton S, Yesilkaya H, McKechnie K, Andrew PW. Development and characterization of a long-term murine model of Streptococcus pneumoniae infection of the lower airways. Infect Immun. 2014; 82:3289-3298.

9. Leggiadro RJ. Bacterial coinfections in lung tissue specimens from fatal cases of 2009 pandemic influenza A (H1N1)-United States, May-August 2009. Pediatr Infect Dis J. 2009;58:1071-1074.

10. Lee EH, Wu C, Lee EU, Stoute A, Hanson H, Cook H A, et al. Fatalities associated with the $2009 \mathrm{H} 1 \mathrm{~N} 1$ influenza A virus in New York city. Clin Infect Dis. 2010; 50:1498-504.

11. Bosshart $H$, Heinzelman M. Targeting bacterial endotoxin two sides of a coin. Ann N Y Acad Sci 2007;1096:1-17.

12. Myc A, Buck J, Gonin J, Reynolds B, Hammerling U, Emanuel D. The level of lipopolysaccharide-binding protein is significantly increased in plasma in patients with the systemic inflammatory response syndrome. Clin Diagn Lab Immunol.1997;19:113-136.

13. Castro AM. In Bacteriología médica basada en problemas. Second edition. Mexico: El Manual Moderno. 2014. p: 37-88.

14. Chertow DS, Memoli MJ. Bacterial coinfection in influenza: a grand rounds review. JAMA. 2013;309:275-282.

15. Wu Y, Tu W, Lam KT, Chow KH, Ho PL, Guan Y, Peiris JS, et al. Lethal coinfection of influenza virus and Streptococcus pneumoniae lowers antibody response to influenza virus in lung and reduces numbers of germinal center B cells, T follicular helper cells, and plasma cells in mediastinal lymph node. J Virol. 2015;89:2013-223.

16. Walters KA, D'Agnillo F, Sheng ZM, Kindrachuk J, Schwartzman LM, Keustne RE, et al. 1918 pandemic influenza virus and Streptococcus pneumoniae coinfection results in activation of coagulation and widespread pulmonary thrombosis in mice and humans. J Pathol. 2016;238:85-97. 